\title{
Carbon fluxes through estuarine bacteria reflect coupling with phytoplankton
}

\author{
Xosé Anxelu G. Morán ${ }^{1, *}$, Hugh W. Ducklow ${ }^{2,3}$, Matthew Erickson ${ }^{2}$ \\ ${ }^{1}$ Instituto Español de Oceanografía, Centro Oceanográfico de Xixón, Camín de L'Arbeyal, s/n 33212 Xixón, Asturies, Spain \\ ${ }^{2}$ The Ecosystems Center, 7 MBL Street, Woods Hole, Massachusetts 02543-1015, USA \\ ${ }^{3}$ Present address: Lamont Doherty Earth Observatory, Palisades, New York 10964, USA
}

\begin{abstract}
Microbial plankton carbon fluxes were comprehensively assessed at 4 contrasting sites in Waquoit Bay estuary (Massachusetts, USA) in 2008, focussing on the role of phytoplankton as dissolved organic matter suppliers for heterotrophic bacterioplankton. Strong seasonal patterns in environmental and microbial variables were observed, with concurrent summer maxima and minima in December for bacterial biomass $\left(17.7-164.7 \mu \mathrm{g} \mathrm{Cl} l^{-1}\right)$ and production $\left(4.8-121.5 \mu \mathrm{g} \mathrm{Cl} \mathrm{l}^{-1}\right.$ $\left.\mathrm{d}^{-1}\right)$. Phytoplankton biomass $\left(0.7-32.6 \mu \mathrm{g}\right.$ chlorophyll $\left.\mathrm{l}^{-1}\right)$ and primary production (PP, 164-3570 $\mu \mathrm{g} \mathrm{C}^{-1} \mathrm{~d}^{-1}$ ) varied similarly to bacterial variables, with dissolved PP (DPP), i.e. released extracellularly, ranging from 3 to $36 \%$ of the total PP. The flux of DPP represented between 0.4 and $20 \%$ of bulk dissolved organic carbon (DOC, 92-346 $\mu \mathrm{mol} \mathrm{C} \mathrm{l}^{-1}$ ) daily turnover. In addition to temperature, moderate bottom-up control of bacterial assemblages was suggested by biomass-production regressions. Bacteria apparently depended more on phytoplankton-derived DOC than on its total concentration. The difference became larger when the total flux of carbon or bacterial carbon demand (BCD, 19-468 $\mu \mathrm{g} \mathrm{C} \mathrm{l}^{-1} \mathrm{~d}^{-1}$ ) was considered, with DPP explaining $53 \%$ of its variance compared with $37 \%$ from bulk DOC. On average, DPP could meet $50 \%$ of BCD, indicating a larger than expected trophic dependence of bacteria on phytoplankton in the whole estuarine ecosystem.
\end{abstract}

KEY WORDS: Bacteria $\cdot$ Phytoplankton $\cdot$ Carbon fluxes $\cdot$ Trophic coupling $\cdot$ Estuaries

\section{INTRODUCTION}

The importance of pelagic bacteria in processing organic carbon in aquatic ecosystems is well established (Cotner \& Biddanda 2002). The amount of dissolved organic carbon (DOC) consumed or bacterial carbon demand (BCD) is subsequently used for bacterial production (BP) and respiration (BR), with usually a greater fraction being returned as $\mathrm{CO}_{2}$. These variables are regulated by bacterial growth efficiency $(\mathrm{BGE}=\mathrm{BP} / \mathrm{BCD})$, which has been reported to vary widely but usually shows higher values in nutrient-rich waters (del Giorgio \& Cole 1998). In marine coastal and estuarine ecosystems, bacteria usually process more carbon than is produced in situ, result- ing in net heterotrophy of the system (e.g. Hoch \& Kirchman 1993, Thottathil et al. 2008). However, in the terrestrial-marine transition zone, recently produced DOC, either released by phytoplankton (here termed dissolved primary production, DPP) or by macrophytes is preferred to older, frequently terrestrially-derived sources (e.g. Norrman et al. 1995, Cherrier et al. 1999). Indeed, BGE is usually higher with high-quality DOC (del Giorgio \& Cole 2000). The paradigm of the general trophic dependence of bacteria on phytoplankton has been recently challenged in a review comparing BP and particulate primary production (PPP) (Fouilland \& Mostajir 2010). A drawback of the studies included in this large-scale meta-analysis is that they did not measure DPP and 
BCD, the most pertinent variables for assessing phytoplankton-bacterioplankton coupling (Morán et al. 2002a). Rather, these 2 variables were estimated from literature models largely differing in assumptions and results (Fouilland \& Mostajir 2011, Morán \& Alonso-Sáez 2011).

$\mathrm{BP}$ is by far the most common variable reported in studies of aquatic carbon fluxes mediated by heterotrophic prokaryotes due to the widespread use of leucine (Leu) and thymidine (TdR) incorporation methods (Kemp et al. 1993). However, the choice of theoretical or empirical substrate to C conversion factors (Ducklow 2000, Alonso-Sáez et al. 2010) may substantially alter the resulting BP values (CalvoDíaz \& Morán 2009). This uncertainty is further complicated with the need to obtain BCD for constraining the total amount of carbon flowing through bacteria (Gasol et al. 2008). When BR measurements are not available (which occurs frequently), BR or BGE values can be obtained from modelled relationships (del Giorgio \& Cole 2000, Rivkin \& Legendre 2001, López-Urrutia \& Morán 2007, Robinson 2008). Similarly, only PPP is typically measured in most estimates of planktonic $\mathrm{PP}$, despite the variable importance of DPP — the flux of photosynthate directly available for bacterial uptake - to total PP values in coastal waters (ca. $20 \%$ on average, but reported variations from $<5 \%$ to $>50 \%$, Teira et al. 2001, Morán et al. 2002b, Marañón et al. 2004). As a consequence, claims that BP globally accounts for 10 to $20 \%$ of concurrent PPP in marine pelagic ecosystems (Ducklow 2000) may be substantially altered if BCD and DPP are the variables compared (Fouilland \& Mostajir 2010, Morán \& Alonso-Sáez 2011). Few studies have assessed these fluxes in estuarine waters.

Many factors interact to determine the amount and fate of the carbon processed by heterotrophic bacterioplankton. Among them, the quality of the available DOC and temperature are arguably the most important (White et al. 1991, Church 2008), although disentangling true temperature effects from covarying drivers is difficult (Pomeroy \& Wiebe 2001, Lomas et al. 2002, Kirchman et al. 2009). The aims of this study were (1) to describe the temporal variability in carbon flow through heterotrophic bacteria specifically addressing the conversion from Leu uptake to carbon biomass production - in an estuarine region characterized by different inorganic and organic nutrient loadings, and (2) to assess the importance of phytoplankton DPP in providing substrates for bacterial growth and metabolism. Experimental determinations were carried out in the estuarine ecosystem of Waquoit Bay (Massachusetts, USA) during
2008, covering a complete growing season of microbial plankton (Morán et al. 2011).

\section{MATERIALS AND METHODS}

\section{Sampling site and environmental variables}

The estuarine ecosystem of Waquoit Bay $\left(41^{\circ} 34^{\prime} \mathrm{N}\right.$, $70^{\circ} 31^{\prime} \mathrm{W}$, Fig. 1) belongs to the US network of National Estuarine Research Reserves (Apple et al. 2008). The shallow morphology and large amounts of nutrient loading received in the upper riverine reaches render it a meso- to eutrophic estuary dominated by macrophytes and benthic processes (Valiela et al. 1992). Waquoit Bay is made up of various subestuaries characterized by dissimilar nitrogen inputs caused by different land use. Relatively pristine areas coexist with heavily populated watersheds, therefore offering a wide range of environmental conditions (Valiela et al. 1997). The comprehensive assessment of carbon flow through heterotrophic bacterioplankton was conducted 6 times in 2008 from May to December in 3 sub-estuaries, Childs River, Quashnet River, Sage Lot Pond, as well as in Nantucket Sound coastal waters off the entrance canal. Sampling was conducted in $\sim 4$ hours by filling 3 acidwashed, rinsed Nalgene carboys over the side of a small boat at each site (Fig. 1). These 3 water samples were taken within an area roughly equivalent to a 10 m diameter circle. In situ measurements and samples for inorganic and organic nutrients, chlorophyll and PP were taken and processed as detailed in Morán et al. (2011).

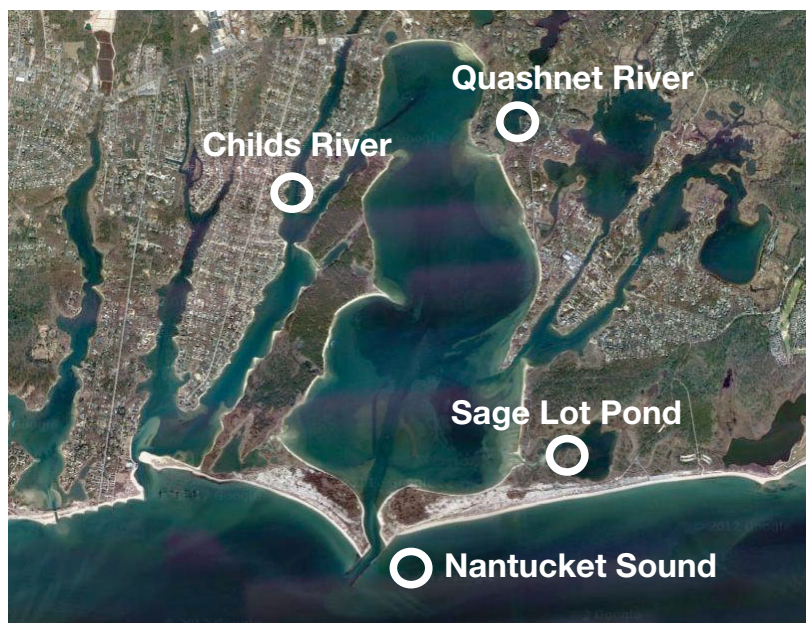

Fig. 1. Waquoit Bay (Cape Cod, Massachusetts, USA, $41^{\circ} 34^{\prime} \mathrm{N}, 70^{\circ} 31^{\prime} \mathrm{W}$ ) showing the 4 study sites (open circles). Image provided by Google Earth 


\section{Bacterial abundance, size and biomass}

Bacterial abundance - the sum of low (LNA) and high (HNA) nucleic acid content cells - was determined by flow cytometry on a Becton-Dickinson FACSCalibur following the protocol of del Giorgio et al. (1996) as discussed in Gasol \& del Giorgio (2000) but using Sybr-Green (Applied Biosystems) as stain. Cell size in biovolume (BBv) was individually determined for LNA and HNA cells as described in Morán et al. (2011) and averaged for each site and sampling time. All samples were processed within 2 weeks after collection. Bacterial biomass was calculated from mean cell size using Norland's (1993) relationship.

\section{Bacterial production and carbon demand}

Bacterial activity was estimated in the 3 replicate samples per site as Leu incorporation rates as detailed elsewhere (Morán et al. 2011). The time scale and irradiance conditions were the same for bacteria and phytoplankton, making assessment of their trophic dependence more comparable. Activity was subsequently transformed into BP by means of empirically determined Leu to carbon conversion factors (Leu-to-C CFs) obtained with the cumulative method (Ducklow et al. 1992) in dilution re-growth experiments (Calvo-Díaz \& Morán 2009). Experimental determinations of Leu-to-C CFs were performed with water from the 1 st of the 3 replicate samples. The coefficient of variation of the 3 Leu incorporation replicates averaged $17 \%$, so we applied the same CF to the other 2 replicates.

In order to constrain the total flux of carbon through heterotrophic bacteria, BCD was first obtained by adding estimates of BR using the literature models of López-Urrutia \& Morán (2007) and Robinson (2008) to our measured BP values. These 2 models rely on different variables for estimating BR: temperature and bacterial abundance in the former, and BP in the latter. On 15 occasions (2 to 4 sub-estuaries per sampling time from May through October) BGE was also empirically determined in long-term DOC consumption experiments in which $50 \mathrm{ml}$ unfiltered water samples were incubated in duplicates in the dark at in situ temperature $\left( \pm 1^{\circ} \mathrm{C}\right)$ for up to $25 \mathrm{~d}$. At intervals ( 1 to $2 \mathrm{~d}$ at the beginning and then weekly), samples were filtered through pre-combusted GF/F filters to estimate DOC while aliquots were also taken to estimate bacterial biomass (BB) as described above. BGE was calculated as the increase of $\mathrm{BB}$ divided by the amount of DOC consumed during the exponential phase, which averaged $4 \mathrm{~d}$ with a range of 1 to $21 \mathrm{~d}$. Mean BGE values at each sub-estuary were 0.12 at Quashnet River, 0.10 at Nantucket Sound, 0.22 at Sage Lot Pond and 0.15 at Childs River.

\section{Statistics}

Except temperature, salinity and percentages, all variables were $\log _{10}$ transformed in order to attain normality and homogeneity of variance for subsequent correlation and regression analyses. Pearson's product-moment correlations, ordinary least squares or Model I linear regressions, paired $t$-tests, and multiple linear regressions were performed with STATISTICA software, v. 7.1 (StaSoft). We used the Akaike information criterion (AIC) to select between the different multiple linear regression models. We first considered all models with $\triangle \mathrm{AIC} \leq 2$ units from that with minimal AIC value, but finally we selected only those with AIC weights higher than 0.15. Differences between sub-estuaries were assessed by means of repeated measures analyses of variance (RMANOVA) and Bonferroni post-hoc tests at $\mathrm{p}<0.05$, with site as between-subject factor (within-subject factor, sampling time).

\section{RESULTS}

\section{Environmental variability}

Seasonal changes in temperature (Fig. 2A) were larger than those of salinity (Fig. 2B), which reflected the expected influence of rivers (Fig. 2A). Chlorophyll (Fig. 2C) attained significantly higher values at the 2 river-influenced sites, with maxima generally observed in July and minima in May or October.

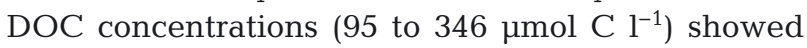
marked spatial differences, with higher values consistently observed at Sage Lot Pond, followed by similar values at both rivers and minima at Nantucket Sound (Fig. 2D). These geographical differences also held for DON concentrations (7.6 to $29.5 \mu \mathrm{mol} \mathrm{N}{ }^{-1}$, data not shown) but seasonality differed markedly, thereby affecting DOM C:N ratios. A maximum ratio of 12 from July through October with values around 6 at the beginning and end of the sampled period was found at the 2 riverine sites, compared with the rather constant (12 to 14) values at Sage Lot Pond and a steady increase from 10 to 15 at Nantucket Sound. Phosphate was generally above $0.1 \mu \mathrm{mol} \mathrm{l}^{-1}$ yearround (Morán et al. 2011) while nitrate (data not 

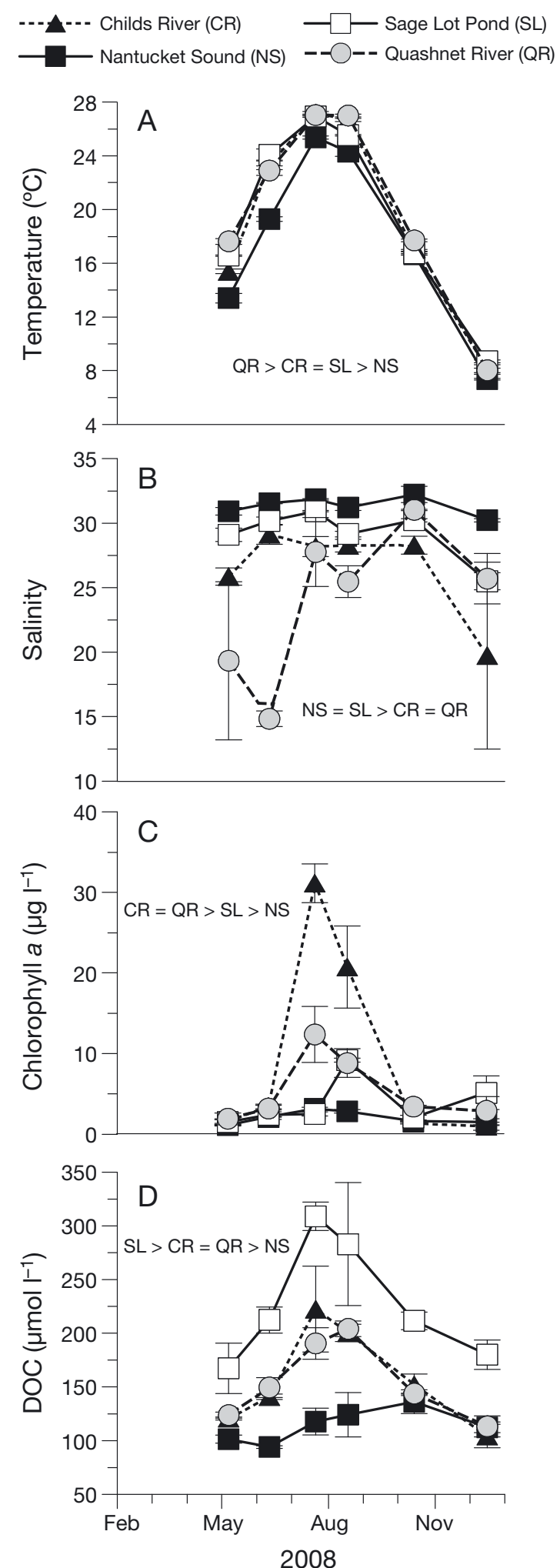

Fig. 2. (A) Mean temperature, (B) salinity, (C) chlorophyll and (D) dissolved organic carbon (DOC) concentrations at the 4 Waquoit Bay sites in 2008. Error bars represent standard deviations of 3 replicates per site. Significant differences between sites are indicated shown), although generally covaried with phosphate, was at times below detection limits as previously reported (McClelland et al. 1997).

\section{Phytoplanktonic PP}

Daily PP rates closely followed changes in phytoplankton standing stocks (Fig. 2C). The sum of the particulate and dissolved fractions and parallel estimates of total PP (from unfiltered aliquots, see full details in Morán et al. 2011) were highly correlated ( $\mathrm{r}=$ $0.95, \mathrm{p}<<0.001, \mathrm{n}=24$ ), although the latter gave slightly higher values (paired $t$-test, $\mathrm{p}=0.02$ ). PPP was usually highest at Childs River $\left(979 \pm 421 \mu \mathrm{g} \mathrm{C}^{-1} \mathrm{~d}^{-1}\right.$, mean $\pm \mathrm{SE})$ and Quashnet River $\left(832 \pm 307 \mu \mathrm{g} \mathrm{C} \mathrm{l}^{-1}\right.$ $\mathrm{d}^{-1}$ ) and very similar except in August at Nantucket Sound and Sage Lot Pond $(251 \pm 50$ and $429 \pm 157 \mu \mathrm{g}$ $\mathrm{C}^{-1} \mathrm{~d}^{-1}$, respectively, Fig. 3A). DPP showed higher temporal and spatial differences compared to PPP (Fig. 3B), yielding different patterns in percent extracellular release (PER) values. PER was usually $<20 \%$, with the conspicuous summer exception of Sage Lot Pond (Fig. 3C), which showed the largest range of variation ( 7 to $36 \%$ ). PER was essentially constant at Nantucket Sound ( 15\%), while Childs River and Quashnet River showed no clear patterns. DPP and bulk DOC values covaried both within (except at Nantucket Sound, $\mathrm{r}=0.58-0.8, \mathrm{p}<0.05, \mathrm{n}=6$ ) and across sites (Table 1), suggesting that phytoplankton fluxes partially accounted for DOM variability in the estuary. DPP/DOC ranged between 0.004 and $0.20 \mathrm{~d}^{-1}$ and increased with temperature (Table 1).

\section{$B B$ and BP}

Heterotrophic BB varied 6-fold, with maxima uniformly found in August (80 to $164 \mathrm{\mu g} \mathrm{C}^{-1}$ ) and minima in December $\left(\sim 30 \mu \mathrm{g} \mathrm{C}^{-1}\right)$, and a clearly decreasing geographical gradient from Childs River to Nantucket Sound (Fig. 4A). The observed variability in BB was largely driven by changes in total abundance although geographical differences in cell size were also observed (RMANOVA $\mathrm{p}=0.003$ ), with values at Nantucket Sound $\left(0.0051 \pm 0.0001 \mu^{-3}\right.$, mean $\pm \mathrm{SD}$ ) being significantly lower (Bonferroni post-hoc test) than at Quashnet River $\left(0.0063 \pm 0.0010 \mu^{-3}\right)$ and Sage Lot Pond $\left(0.0058 \pm 0.0002 \mu \mathrm{m}^{-3}\right)$ with intermediate values found at Childs River (0.0055 \pm

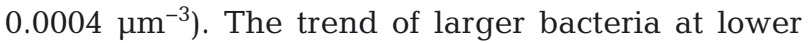
salinities could be caused by increasing DON concentrations with more freshwater present (Table 1). 

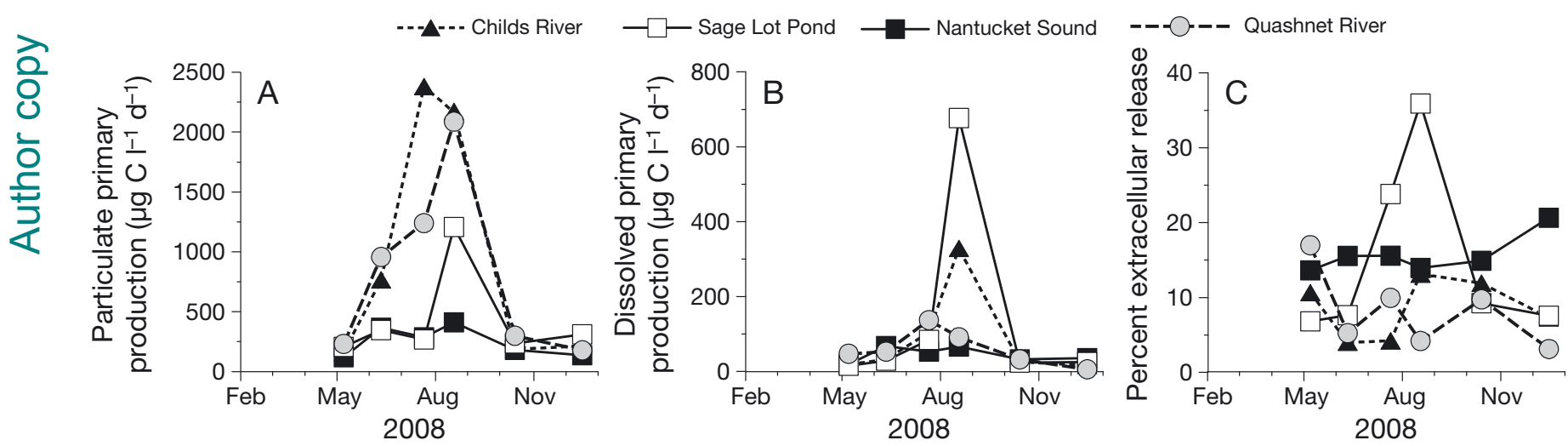

Fig. 3. Measured rates of (A) particulate, (B) dissolved primary production and (C) percent extracellular release (i.e. contribution of dissolved primary production to total primary production) in Waquoit Bay

Table 1. Pearson correlation coefficients between selected environmental variables, dissolved primary production and bacterial biomass and production in Waquoit Bay during 2008. Temp: temperature; Salt: salinity; Chl: chlorophyll; DPP: dissolved primary production, DPP/DOC: contribution of DPP to total DOC turnover; BBv: mean cell size; BB: bacterial biomass; LIR: leucine incorporation rates; LCF: Leu-to-C conversion factors, BP: bacterial production. Except for temperature, salinity and DPP/DOC, all variables were $\log _{10}$ transformed. $\mathrm{n}=72$ except DPP, DPP/DOC and LCF, for which $\mathrm{n}=24$. Significant $(\mathrm{p}<0.05)$ correlations are indicated in bold when the level of significance was $p<0.00083$ after Bonferroni correction

\begin{tabular}{|c|c|c|c|c|c|c|c|c|c|c|c|}
\hline & Temp & Salt & DOC & DON & $\mathrm{Chl}$ & DPP & DPP/DOC & $\mathrm{BBv}$ & BB & LIR & $\mathrm{LCF}$ \\
\hline Salt & - & & & & & & & & & & \\
\hline DOC & 0.57 & - & & & & & & & & & \\
\hline DON & - & -0.41 & 0.31 & & & & & & & & \\
\hline Chl & 0.63 & - & 0.56 & - & & & & & & & \\
\hline DPP & 0.73 & - & 0.55 & - & 0.70 & & & & & & \\
\hline DPP/DOC & 0.47 & - & - & - & 0.57 & 0.87 & & & & & \\
\hline $\mathrm{BBv}$ & - & -0.29 & - & 0.36 & - & - & - & & & & \\
\hline $\mathrm{BB}$ & 0.87 & - & 0.64 & - & 0.75 & 0.75 & 0.55 & - & & & \\
\hline LIR & 0.75 & - & 0.46 & - & 0.41 & 0.56 & - & 0.38 & 0.68 & & \\
\hline $\mathrm{LCF}$ & - & 0.61 & - & - & - & - & - & - & - & -0.57 & \\
\hline $\mathrm{BP}$ & 0.74 & - & 0.41 & - & 0.34 & 0.51 & - & - & 0.62 & 0.90 & - \\
\hline
\end{tabular}

The overall high Leu incorporation rates (162 to 6562 pmol Leu $\mathrm{l}^{-1} \mathrm{~h}^{-1}$ ) showed distinct spatio-temporal patterns, with maxima in summer and a sharp decline towards December minima at all sites (Fig. 4B). Highest values at Quashnet River were only significantly higher than those at Nantucket Sound, which were also significantly lower than Sage Lot Pond values. Bacterial activity was significantly correlated with temperature, DPP, DOC and cell size (Table 1).

Leu-to-C CFs varied $\sim 2.5$-fold within sites, with generally 2 relative maxima, in June and October or December and minima in May and July (Fig. 4C). Values increased with salinity but decreased with Leu incorporation rates (Table 1), resulting in lower variability of production (Fig. 4D) relative to activity (Fig. 4B) and not significantly different values between sub-estuaries (RMANOVA, $\mathrm{p}=0.10$ ). Overall, $\mathrm{BP}$ varied 2 orders of magnitude (4.8 to $121.5 \mu \mathrm{g} \mathrm{C} \mathrm{l}^{-1}$ $\mathrm{d}^{-1}$ ), with maxima found in July and minima in December.
Modelled bacterial respiration varied over 2 orders of magnitude: 8.5 to $408 \mu \mathrm{g} \mathrm{Cl}^{-1} \mathrm{~d}^{-1}$ according to LópezUrrutia \& Morán (2007) $\left(\mathrm{BR}_{1}\right)$ and 26 to $170 \mu \mathrm{g} \mathrm{Cl}^{-1} \mathrm{~d}^{-1}$ according to Robinson (2008) $\left(\mathrm{BR}_{2}\right)$. Individual $\mathrm{BGE}$ values calculated in the long-term DOC consumption experiments (range 3 to $50 \%$ ) compared reasonably well with BGEs estimated as $\mathrm{BP} /\left(\mathrm{BP}+\mathrm{BR}_{1}\right)(4$ to $70 \%)$, and $\mathrm{BP} /\left(\mathrm{BP}+\mathrm{BR}_{2}\right)(16$ to $42 \%)$, with a common mean value of $29 \%$. Although the independent variables for estimating $\mathrm{BR}_{1}$ and $\mathrm{BR}_{2}$ differed, both $\mathrm{BCD}$ estimates were strongly correlated $(r=0.80, p<0.001, n=72)$ and were not significantly different (paired $t$-test, $\mathrm{p}=$ $0.11, \mathrm{n}=72$ ). BCD calculated from the DOC consumption-based BGE values was also strongly correlated with the 2 aforementioned estimates $(r=0.85$ and 0.92 , respectively, $\mathrm{p}<0.001, \mathrm{n}=24$ ). However, since the empirical BGEs were not available for all sites and sampling times, we decided to use BCD values of the 1st model, which ranged from to 19 to $468 \mu \mathrm{g} \mathrm{C} \mathrm{l}^{-1} \mathrm{~d}^{-1}$, except when indicated otherwise. 

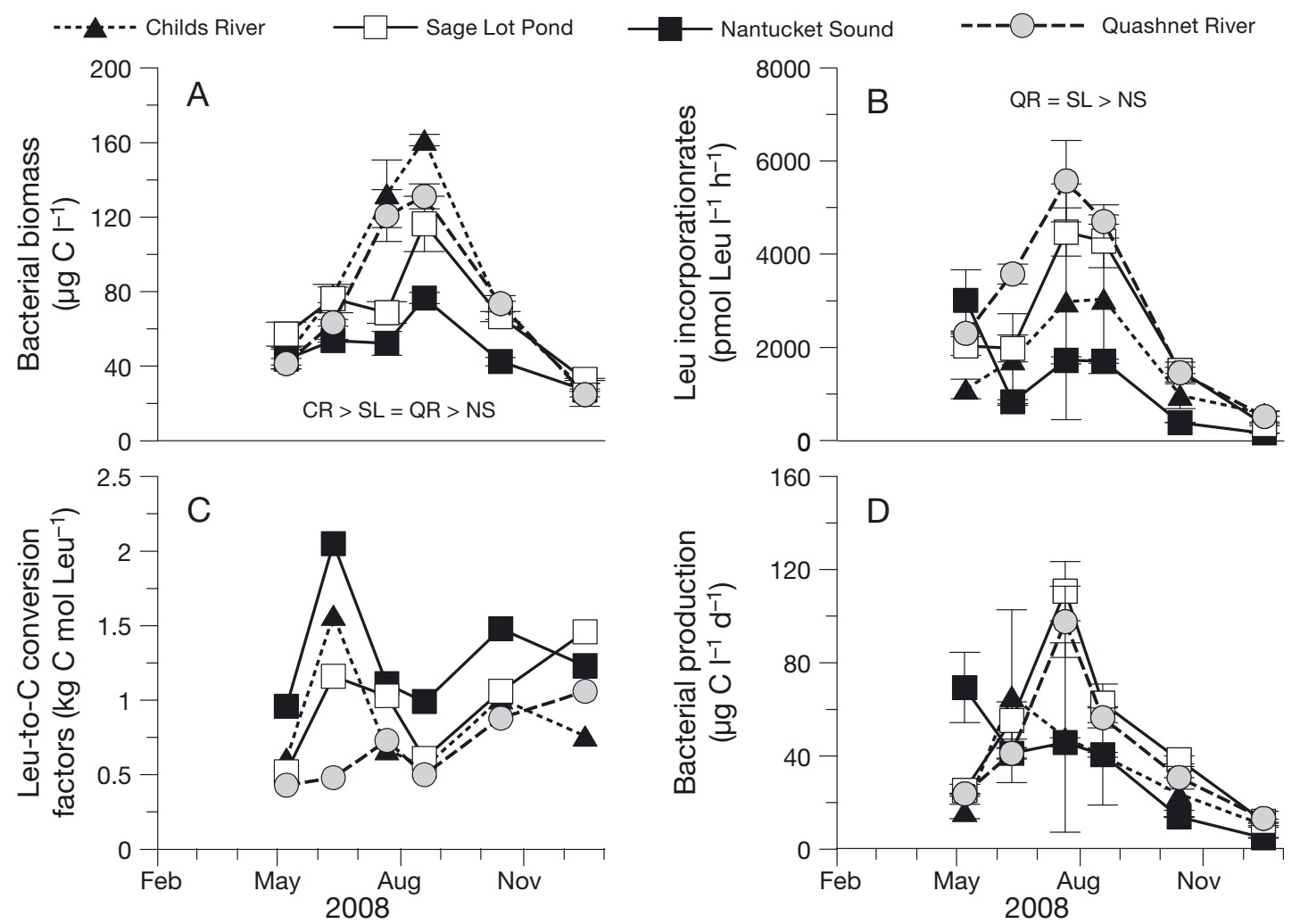

Fig. 4. (A) Mean bacterial biomass, (B) leucine incorporation rates, (C) Leu-to-C conversion factors and (D) bacterial production in Waquoit Bay. Error bars represent standard deviations of 3 replicates per site. In (C) only 1 replicate per site was carried out. Significant differences between sites are indicated in (A) and (B). In (D) the between-effect was not significant (RMANOVA, $\mathrm{p}>0.05)$

\section{Controls of bacterial carbon flow}

Good relationships were generally found in Waquoit Bay between bacterial biomass and Leu incorporation rates, a slight modification (Morán et al. 2010) of the assessment of bottom-up (resource) control suggested by Billen et al. (1990) and Ducklow (1992). With all data pooled, the slope of the log-log regression was 0.38 , indicating close to moderate bottom-up control. The biomass-activity regressions varied across sites (Table 2), with absolute bottom-up control ranging from weak at Nantucket Sound to strong at Quashnet River.

Two candidates for exerting substrate control are DOC and the fraction of recent phytoplanktonic origin (DPP). Similar to LIR, BP was also significantly correlated with both of these variables (Table 1, Fig. 5B,C), with DPP explaining a higher percentage of total variance ( $26 \mathrm{vs} .17 \%$ ). In an attempt to differentiate between bulk and phytoplanktonic DOC we performed multiple linear regressions with DOC, DON, DOC:DON and DPP as potential explanatory variables $(\mathrm{n}=24)$. For bacterial biomass the best models were:
Table 2. Slopes of the log bacterial biomass vs. log leucine incorporation rates linear regressions with all data pooled $(\mathrm{n}=72)$ and at each of the 4 Waquoit Bay sites $(\mathrm{n}=18)$ with the indication of statistical significance and the strength of bottom-up control following Ducklow (1992)

\begin{tabular}{|lccrc|}
\hline & Slope & $\mathrm{r}^{2}$ & $\mathrm{p}$ & $\begin{array}{c}\text { Bottom-up } \\
\text { control }\end{array}$ \\
\hline Waquoit Bay & 0.38 & 0.68 & $<0.001$ & Weak \\
Childs River & 0.36 & 0.22 & 0.048 & Weak \\
Nantucket Sound & 0.25 & 0.51 & 0.001 & Weak \\
Sage Lot Pond & 0.41 & 0.59 & $<0.001$ & Moderate \\
Quashnet River & 0.85 & 0.86 & $<0.001$ & Strong \\
\hline
\end{tabular}

(1) $\log \mathrm{BB}=0.09+0.56 \log \mathrm{DOC}+0.29 \log \mathrm{DPP}$ $\mathrm{AIC}=-21.8$, AIC weight $=0.39, \mathrm{r}^{2}=0.65$

(2) $\log \mathrm{BB}=-0.30-0.05 \mathrm{DOC}: \mathrm{DON}+1.52 \log$ $\mathrm{DOC}-0.92 \log \mathrm{DON}+0.27 \log \mathrm{DPP}$, AIC $=-21.4$, AIC weight $=0.31, \mathrm{r}^{2}=0.70$

The best models for bacterial production included the following variables:

(1) $\log \mathrm{BP}=-2.18-0.16 \mathrm{DOC}: \mathrm{DON}+3.87 \log$ $\mathrm{DOC}-2.59 \log \mathrm{DON}, \mathrm{AIC}=7.23$,

AIC weight $=0.36, \mathrm{r}^{2}=0.45$ 

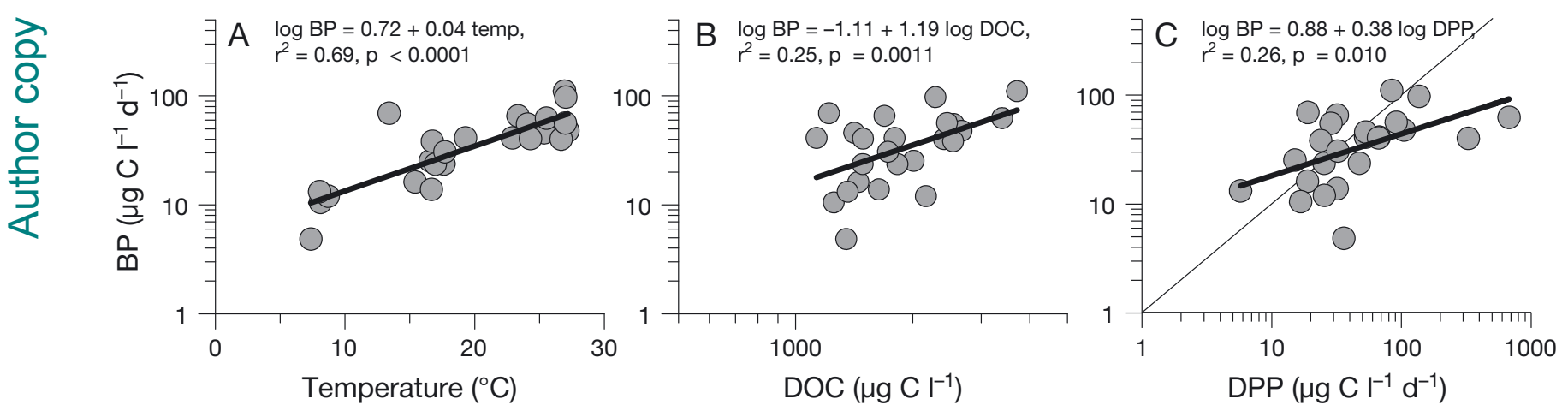

Fig. 5. Relationships between bacterial production (BP) and (A) temperature, (B) dissolved organic carbon (DOC) concentration and (C) dissolved primary production (DPP) rates for all data pooled. Continuous line in (C) represents the 1:1 relationship. All data except DPP are mean values of 3 replicates per site and sampling time. Fitted lines are ordinary least squares linear regressions. $n=24$

$$
\begin{aligned}
& \log \mathrm{BP}=-1.67-0.15 \mathrm{DOC}: \mathrm{DON}+3.32 \log \\
& \text { DOC }-2.37 \log \mathrm{DON}+0.23 \log \mathrm{DPP}, \\
& \text { AIC }=7.56, \text { AIC weight }=0.30, \mathrm{r}^{2}=0.51
\end{aligned}
$$

Both bulk DOC and DPP explained higher percentages of variance when the total flux of carbon $(\mathrm{BP}+$ $\mathrm{BR}$ ) was considered. Moreover, DPP was a better predictor of $\mathrm{BCD}$ than bulk DOC regardless of the method used for estimating $B R$, the literature model (Fig. 6A) or the mean BGE values calculated for each site (Fig. 6B), In the latter case, only the linear regression with DPP was significant, providing stronger support to the role played by fresh photosynthate in fuelling bacterial metabolism.

This bacterial dependence on DPP differed between sub-estuaries (Fig. 7), Although BCD exceeded DPP on all except 2 occasions, released photosynthate could sporadically meet most bacterial requirements of carbon at the 4 sites. DPP/BCD ratios show that bacterial requirements for substrates could be provided mainly by phytoplankton (i.e. DPP/BCD >0.5) on one third of the determinations, with no obvious temporal pattern (Fig. 7). Site-averaged values reflect that the contribution of DPP to BCD was higher in Sage Lot Pond and Nantucket Sound $(64 \%$ and $60 \%$, respectively) compared with the 2 riverine sites (39\% at Childs River and 35\% at Quashnet River). For the whole bay, DPP/BCD averaged $0.50 \pm 0.11$.

\section{DISCUSSION}

\section{Spatio-temporal variability of microbial carbon fluxes}

Most physico-chemical and microbial plankton variables displayed strong between-site differences in Waquoit Bay (Figs. 2 \& 3), largely dependent on

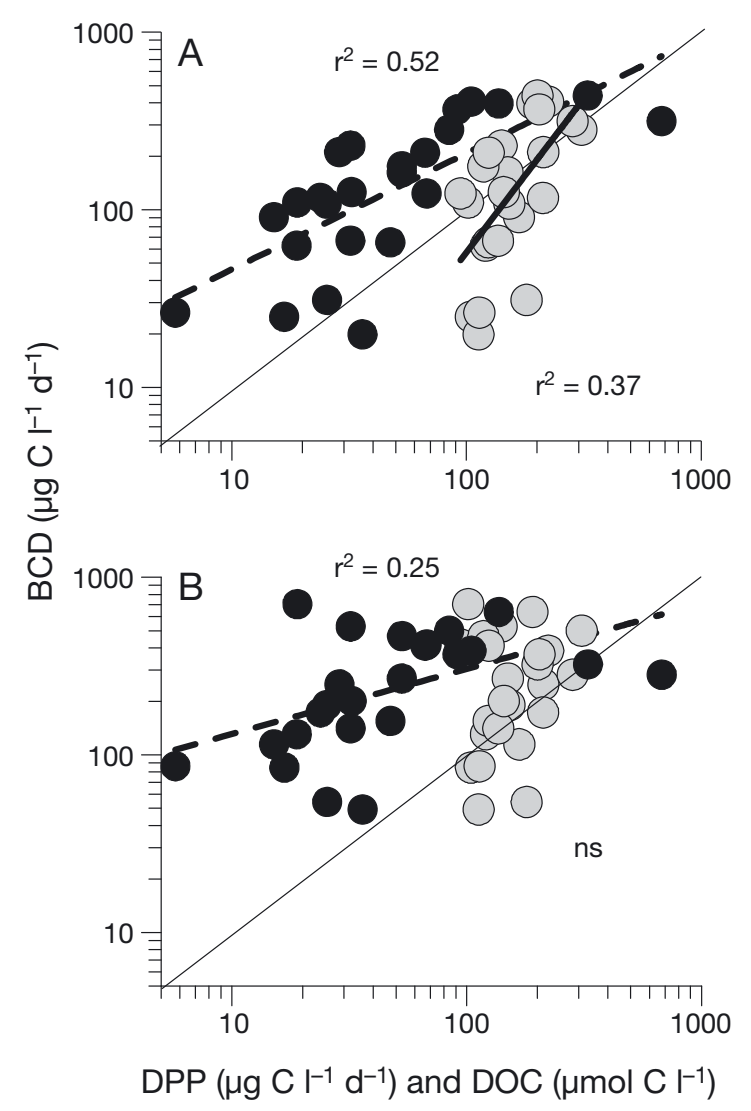

Fig. 6. Relationships between bacterial carbon demand (BCD) and dissolved primary production rates (DPP) and bulk dissolved organic carbon (DOC) concentrations for all Waquoit Bay data pooled using (A) the literature model of López-Urrutia \& Morán (2007) for estimating bacterial respiration and (B) site-averaged empirical bacterial growth efficiencies obtained in long-term DOC consumption experiments. Note the different units for DPP and DOC on the $x$-axis. Fitted dashed and continuous lines represent significant $(\mathrm{p}<0.05)$ BCD-DPP and BCD-DOC correlations, respectively. Coefficients of determination are also given. ns: non significant 


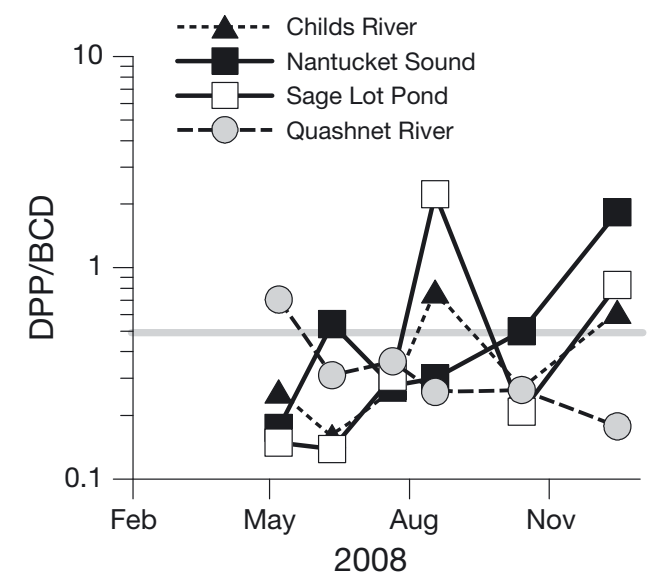

Fig. 7. Temporal evolution of the relative contribution of dissolved primary production to bacterial carbon demand (DPP/BCD). Grey line represents a DPP/BCD value of 0.50 (i.e. values above the line indicate that DPP would meet more than $50 \%$ of total BCD)

the varying influence of riverine nutrient inputs (Valiela et al. 1992, 1997, Martinetto et al. 2006) and associated changes in ecosystem functioning (McClelland \& Valiela 1998, Olsen et al. 2011). Standing stocks and productivities tended to be higher at the freshwater-influenced sites Childs River and Quashnet River and usually the lowest values were found in coastal waters outside of the estuary mouth. Withinsite differences in external forcings relevant for bacterial metabolism were more evident for bulk and phytoplankton-derived DOM (Fig. 2D and 3B) than for temperature (Fig. 2A).

PPP and DPP did not always covary, causing conspicuous differences in PER between sites (Fig. 3C). Although high PP is frequently associated with low PER (Nagata 2000), values $>20 \%$, perhaps caused by enhanced grazing activity (Teira et al. 2001) or transient inorganic nutrient limitation (Obernosterer \& Herndl 1995), were found 3 times in Waquoit Bay. Strong nutrient and salinity gradients are likely behind the order of magnitude variation in PER, far from the hypothesized constancy at $20 \%$ in marine waters (Marañón et al. 2005). Interestingly, PER was more constant in Nantucket Sound coastal waters outside the estuary. Low PER variability was reported in stable environments compared to others experiencing high frequency physico-chemical forcing (Morán \& Estrada 2001), like that expected upstream of the bay associated to changes in river discharge. A shift in the dominant phytoplankton species, with an increase in the Synechococcus to picoeukaryotes ratio in July and August (data not shown) could also be behind the substantial PER increase observed at Sage Lot Pond.
Spatio-temporal patterns in bacterial activity did not have a straightforward translation into production (cf. Fig. 4B,D) due to 4.8-fold variation in Leu-toC CFs (Fig. 4C). Seasonal variations in tracer to carbon CFs had been previously documented for Leu (Alonso-Sáez et al. 2008, Calvo-Díaz \& Morán 2009) and TdR (Kirchman et al. 1982), strongly cautioning against the use of fixed literature values. In spite of the overall nutrient-rich nature of Waquoit Bay waters, Leu-to-C CFs close to either 1.55 or $3.1 \mathrm{~kg} \mathrm{C}$ $\mathrm{mol} \mathrm{Leu}{ }^{-1}$, based on theoretical assumptions in nutrient replete bacteria (Simon \& Azam 1989), were seldom achieved (Fig. 4C). The weak but inverse correlation with Leu incorporation rates, as in NE Atlantic continental shelf waters (Calvo-Díaz \& Morán 2009), warns against the face value acceptance of activity as indicator of biomass production also in the freshwatersaltwater transition, where the lowest Leu-to-C CFs were surprisingly found in waters more affected by riverine discharge (Table 1 ).

Although the time needed to calculate BGE in the DOC consumption experiments was considerably larger than the $<2 \mathrm{~h}$ needed for measuring Leu incorporation, the corresponding BGE estimates averaged for all sites available at each sampling time (data not shown) displayed a coherent seasonal cycle. Minima occurred in May and October and maxima in June or July, where they reached high values comparable to literature models (ca. 30\%) - as expected for mesoto eutrophic sites, and specifically estuaries (del Giorgio \& Cole 1998, 2000). Within-sites differences also reflected the expected increase in BGE with higher trophic status.

The large variability found across time and space in bacterial biomass and production in Waquoit Bay, likely reflecting the succession of distinct taxa, could be unexpectedly reduced to a few common variables explaining appreciable amounts of variance, as shown in Table 1, Fig. 6 and the multiple linear regressions.

\section{Role of phytoplanktonic DOC in bottom-up control}

Various lines of evidence point towards moderate bottom-up control of bacteria in Waquoit Bay as summarized in Table 2. Bacterial-specific growth rates were more controlled by substrates than by temperature, although temperature effects were also apparent (Morán et al. 2011). Both temperature and substrate supply affected bacterial biomass and production in this study, with the latter having a seemingly preponderant role (Fig. 5 and Table 1). There was no change in the slope of the BP-temperature 
relationship at higher temperatures (Fig. 5A), considered elsewhere as evidence of summer shortage of bacterial substrates (Shiah \& Ducklow 1994, Shiah et al. 1999, Morán et al. 2010). With substrates being available year-round, we aimed to determine to what extent bottom-up control was exerted by phytoplankton. Macrophytes (mostly seaweeds) are the dominant primary producers in Waquoit Bay proper (the 2 rivers and Sage Lot Pond), with phytoplankton contributions to gross PP ranging from 12 to $24 \%$ (D'Avanzo et al. 1996). Although this would leave a minor role of planktonic algae in sustaining bacterial growth, bacteria preferentially assimilate phytoplankton DOC relative to other sources (Norrman et al. 1995, del Giorgio \& Cole 1998), and this preference appears to be widespread in coastal bacteria phylotypes (Sarmento \& Gasol 2012). DPP contribution to DOC turnover was significantly correlated with temperature but temporal changes in the relative degree of total versus phytoplanktonic bottomup control of bacterial assemblages were not evident. Different associations with temperature in the southern Bay of Biscay were explained by strong limitations in phytoplanktonic DOM supply during summer stratification (Morán et al. 2010). In contrast to previous studies (Tomasky \& Valiela 1995, York et al. 2007), the present study found that both phytoplankton biomass and production continued to increase, and also peaked, during the summer (Fig. 3), suggesting that our phytoplankton samples were not strongly limited by inorganic nutrients.

Organic substrates released by phytoplankton are usually a very small fraction of total DOC partly due to their rapid removal from the system by bacteria (Larsson \& Hagström 1979). Interestingly, the correlations between DPP and bulk DOC concentration, indicative of sizeable phytoplanktonic contribution to total DOM fluxes, were significant at the 3 sites inside Waquoit Bay. That DOC concentrations at Childs River and Quashnet River, higher than at Nantucket Sound, also increased with increasing DPP gives further support to our view that phytoplankton products were important components of carbon flowing through bacteria in the whole estuary. Without considering temperature, the best multiple linear regression models for BB and BP always included DPP together with bulk DOM characteristics, explaining 55 to $60 \%$ and 45 to $50 \%$ of the respective variances. Further, DPP explained more variance in $\mathrm{BCD}$ than bulk $\mathrm{DOC}$, regardless of the method used for estimating respiration (Fig. 6). Strictly speaking, bacterioplankton would not be tightly coupled to phytoplankton year-round in
Waquoit Bay according to our definition (Morán et al. 2002a) because BCD exceeded DPP in most of the samples. However, phytoplankton would be the dominant source of substrates for bacteria in $40 \%$ of all determinations (Fig. 7). The BCD-DPP covariation even held for the 2 riverine sites separately (data not shown), reinforcing the important role of dissolved photosynthate in fuelling bacterial metabolism in the entire system. Inside the bay, the highest correlation (0.92) was found at Quashnet River and the lowest at Sage Lot Pond (0.42), where benthic communities were dominated by macroalgae and eelgrass Zostera marina, respectively (Hauxwell et al. 2001, Fox et al. 2008). Interestingly, BGE differs between DOC of these 2 origins, with 3-fold higher values on DOC derived from vascular plants compared with seaweeds (del Giorgio \& Cole 1998). These results suggest that the contribution of DPP to BCD may be also modulated by the quality of other DOC sources. Only a small fraction $(<10 \%)$ of the bulk DOC pool would need to be turned over daily in order to satisfy bacterial needs, consistent with our estimated DPP/DOC values. The concurrent accumulations of bacteria and phytoplankton in eutrophic estuaries would thus not simply indicate common responses to other drivers, but suggest direct, trophic relationships - although the presence of large amounts of semi-labile to refractory DOC may have obscured this finding in the past.

Without considering here the role of sloppy feeding by meso- and micrograzers or cell lysis in supplying extra phytoplankton-derived DOC, DPP alone contributed on average $50 \%$ of bacterial carbon needs in the estuary and surrounding waters during an annual cycle (Fig. 7). When moving along the trophic gradient from freshwater to seawater DPP/BCD increased as predicted by Morán et al. (2002a), with a mean, but still noticeable $37 \%$ at the riverine sites and almost $2 / 3 \mathrm{BCD}$ met by DPP at Nantucket Sound and Sage Lot Pond. Indications of phytoplankton-bacterioplankton coupling in estuaries are not completely new. Bacteria were entirely dependent on DOC of recent origin rather than old DOC in a subtropical mangrove-dominated estuary (Cherrier et al. 1999) while Fouilland \& Mostajir (2010) show that the sum of PPP and DPP was able to meet BCD in highly productive waters $(>100 \mu \mathrm{g}$ $\mathrm{C}^{-1} \mathrm{~d}^{-1}$ ) such as those of Waquoit Bay (Fig. 3). After careful consideration of possible sources of error, we show that the strong seasonal changes were coherent with a major role of phytoplankton in supplying the substrates required for bacterial metabolism. We conclude that the frequently claimed need 
of allochthonous DOM for supporting bacterial growth in estuarine ecosystems should not make us overlook the important function played by photosynthate freshly released by phytoplankton.

Acknowledgements. We thank everyone at The Ecosystems Center (Marine Biological Laboratory), especially S. Aebischer, Y. Luo, K. Meyers, S. Fox, Y. Olsen, and R. Monteiro for their assistance during sampling and experimental work; and I. Valiela for discussion about Waquoit Bay. X.A.G.M was supported by a sabbatical fellowship from the Spanish Ministry of Education and Science.

\section{LITERATURE CITED}

- Alonso-Sáez L, Vázquez-Domínguez E, Cardelús C, Pinhassi J and others (2008) Factors controlling the yearround variability in carbon flux through bacteria in a coastal marine system. Ecosystems 11:397-409

> Alonso-Sáez L, Pinhassi J, Pernthaler J, Gasol JM (2010) Leucine-to-carbon empirical conversion factor experiments: Does bacterial community structure have an influence? Environ Microbiol 12:2988-2997

- Apple JK, Smith EM, Boyd TJ (2008) Temperature, salinity, nutrients, and the covariation of bacterial production and chlorophyll-a in estuarine ecosystems. J Coast Res Spec Issue 55:59-75

Billen G, Servais P, Becquevort S (1990) Dynamics of bacterioplankton in oligotrophic and euphotic aquatic environments: bottom-up or top-down control? Hydrobiologia 207:37-42

Calvo-Díaz A, Morán XAG (2009) Empirical leucine-to-carbon conversion factors for estimating heterotrophic bacterial production: seasonality and predictability in a temperate coastal ecosystem. Appl Environ Microbiol 75: 3216-3221

Cherrier J, Bauer JE, Druffel ERM, Coffin RB, Chanton JP (1999) Radiocarbon in marine bacteria: evidence for the ages of assimilated carbon. Limnol Oceanogr 44:730-736

Church MJ (2008) Resource control of bacterial dynamics in the sea. In: Kirchman DL (ed) Microbial ecology of the oceans, 2nd edn. John Wiley \& Sons, Hoboken, NJ, p 335-382

> Cotner JB, Biddanda BA (2002) Small players, large role: microbial influence on biogeochemical processes in pelagic aquatic ecosystems. Ecosystems 5:105-121

D'Avanzo C, Kremer JN, Wainright SC (1996) Ecosystem production and respiration in response to eutrophication in shallow temperate estuaries. Mar Ecol Prog Ser 141: 263-274

del Giorgio PA, Cole JJ (1998) Bacterial growth efficiency in natural aquatic systems. Annu Rev Ecol Syst 29:503-541

del Giorgio PA, Cole JJ (2000) Bacterial energetics and growth efficiency. In: Kirchman DL (ed) Microbial ecology of the oceans. Wiley-Liss, New York, NY, p 289-325

del Giorgio PA, Bird DF, Prairie YT, Planas D (1996) Flow cytometric determination of bacterial abundance in lake plankton with the green nucleic acid stain SYTO 13. Limnol Oceanogr 41:783-789

Ducklow HW (1992) Factors regulating bottom-up control of bacteria biomass in open ocean plankton communities. Arch Hydrobiol Beih Ergebn Limnol 37:207-217
Ducklow H (2000) Bacterial production and biomass in the oceans. In: Kirchman DL (ed) Microbial ecology of the oceans. Wiley-Liss, New York, NY, p 85-120

> Ducklow HW, Kirchman DL, Quinby HL (1992) Bacterioplankton cell growth and macromolecular synthesis in seawater cultures during the North Atlantic spring phytoplankton bloom, May, 1989. Microb Ecol 24:125-144

Fouilland E, Mostajir B (2010) Revisited phytoplanktonic carbon dependency of heterotrophic bacteria in freshwaters, transitional, coastal and oceanic waters. FEMS Microbiol Ecol 73:419-429

> Fouilland E, Mostajir B (2011) Complementary support for the new ecological concept of 'bacterial independence on contemporary phytoplankton production' in oceanic waters. FEMS Microbiol Ecol 78:206-209

Fox SE, Stieve E, Valiela I, Hauxwell J, McClelland J (2008) Macrophyte abundance in Waquoit Bay: effects of landderived nitrogen loads on seasonal and multi-year biomass patterns. Estuaries Coasts 31:532-541

> Gasol JM, del Giorgio PA (2000) Using flow citometry for counting natural planktonic bacteria and understanding the structure of planktonic bacterial communities. Sci Mar 64:197-224

Gasol JM, Pinhassi J, Alonso-Sáez L, Ducklow H and others (2008) Towards a better understanding of microbial carbon flux in the sea. Aquat Microb Ecol 53:21-38

Hauxwell J, Cebrian J, Furlong C, Valiela I (2001) Macroalgal canopies contribute to eelgrass (Zostera marina) decline in temperate estuarine ecosystems. Ecology 82: 1007-1022

Hoch MP, Kirchman DL (1993) Seasonal and interannual variability in bacterial production and biomass in a temperate estuary. Mar Ecol Prog Ser 98:283-295

Kemp PF, Sherr BF, Sherr EB, Cole JJ (1993) Handbook of methods in aquatic microbial ecology. Lewis Publishers, Boca Raton, FL

- Kirchman D, Ducklow H, Mitchell R (1982) Estimates of bacterial growth from changes in uptake rates and biomass. Appl Environ Microbiol 44:1296-1307

Kirchman DL, Morán XAG, Ducklow H (2009) Microbial growth in the polar oceans - role of temperature and potential impact of climate change. Nat Rev Microbiol 7: 451-459

Larsson U, Hagström ^ (1979) Phytoplankton exudate release as an energy source for the growth of pelagic bacteria. Mar Biol 52:199-206

> Lomas MW, Glibert PM, Shiah FK, Smith EM (2002) Microbial processes and temperature in Chesapeake Bay: current relationships and potential impacts of regional warming. Glob Change Biol 8:51-70

López-Urrutia Á, Morán XAG (2007) Resource limitation of bacterial production distorts the temperature dependence of oceanic carbon cycling. Ecology 88:817-822

Marañón E, Cermeño P, Fernández E, Rodríguez J, Zabala L (2004) Significance and mechanisms of photosynthetic production of dissolved organic carbon in a coastal eutrophic ecosystem. Limnol Oceanogr 49:1652-1666

> Marañón E, Cermeño P, Pérez V (2005) Continuity in the photosynthetic production of dissolved organic carbon from eutrophic to oligotrophic waters. Mar Ecol Prog Ser 299:7-17

Martinetto P, Teichberg M, Valiela I (2006) Coupling of estuarine benthic and pelagic food webs to land-derived nitrogen sources in Walquoit Bay, Massachusetts, USA. Mar Ecol Prog Ser 307:37-48 
McClelland JW, Valiela I (1998) Changes in food web structure under the influence of increased anthropogenic nitrogen inputs to estuaries. Mar Ecol Prog Ser 168: 259-271

McClelland JW, Valiela I, Michener RH (1997) Nitrogen-stable isotope signatures in estuarine food webs: a record of increasing urbanization in coastal watersheds. Limnol Oceanogr 42:930-937

Morán XAG, Alonso-Sáez L (2011) Independence of bacteria on phytoplankton? Insufficient support for Fouilland \& Mostajir's (2010) suggested new concept. FEMS Microbiol Ecol 78:203-205

Morán XAG, Estrada M (2001) Short-term variability of photosynthetic parameters and particulate and dissolved primary production in the Alboran Sea (SW Mediterranean). Mar Ecol Prog Ser 212:53-67

Morán XAG, Estrada M, Gasol JM, Pedrós-Alió C (2002a) Dissolved primary production and the strength of phytoplankton bacterioplankton coupling in contrasting marine regions. Microb Ecol 44:217-223

Morán XAG, Gasol JM, Pedrós-Alió C, Estrada M (2002b) Partitioning of phytoplanktonic organic carbon production and bacterial production along a coastal-offshore gradient in the NE Atlantic during different hydrographic regimes. Aquat Microb Ecol 29:239-252

Morán XAG, Calvo-Díaz A, Ducklow HW (2010) Total and phytoplankton mediated bottom-up control of bacterioplankton change with temperature in NE Atlantic shelf waters. Aquat Microb Ecol 58:229-239

Morán XAG, Ducklow HW, Erickson M (2011) Single-cell physiological structure and growth rates of heterotrophic bacteria in a temperate estuary (Waquoit Bay, Massachusetts). Limnol Oceanogr 56:37-48

Nagata T (2000) Production mechanisms of dissolved organic matter. In: Kirchman DL (ed) Microbial ecology of the oceans. Wiley-Liss, New York, NY, p 121-152

Norland S (1993) The relationship between biomass and volume of bacteria. In: Kemp PF, Sherr BF, Sherr EB, Cole JJ (eds) Handboook of methods in aquatic microbial ecology. Lewis Publishers, Boca Raton, FL, p 303-307

Norrman B, Zweifel UL, Hopkinson CSJ, Fry B (1995) Production and utilization of dissolved organic carbon during an experimental diatom bloom. Limnol Oceanogr 40: 898-907

Obernosterer I, Herndl GJ (1995) Phytoplankton extracellular release and bacterial growth: dependence on the inorganic N:P ratio. Mar Ecol Prog Ser 116:247-257

Olsen YS, Fox SE, Teichberg M, Otter M, Valiela I (2011) $\delta^{15} \mathrm{~N}$ and $\delta^{13} \mathrm{C}$ reveal differences in carbon flow through estuarine benthic food webs in response to the relative availability of macroalgae and eelgrass. Mar Ecol Prog

Editorial responsibility: Graham Savidge, Portaferry, UK
Ser 421:83-96

> Pomeroy LR, Wiebe WJ (2001) Temperature and substrates as interactive limiting factors for marine heterotrophic bacteria. Aquat Microb Ecol 23:187-204

> Rivkin RB, Legendre L (2001) Biogenic carbon cycling in the upper ocean: effects of microbial respiration. Science 291:2398-2400

Robinson C (2008) Heterotrophic bacterial respiration. In: Kirchman DL (ed) Microbial ecology of the oceans, 2nd edn. John Wiley \& Sons, Hoboken, NJ, p 299-334

Sarmento H, Gasol JM (2012) Use of phytoplankton-derived dissolved organic carbon by different types of bacterioplankton. Environ Microbiol 14:2348-2360

Shiah FK, Ducklow HW (1994) Temperature and substrate regulation of bacterial abundance, production and specific growth rate in Chesapeake Bay, USA. Mar Ecol Prog Ser 103:297-308

Shiah FK, Liu KK, Gong GC (1999) Temperature versus substrate limitation of heterotrophic bacterioplankton production acroos trophic and temperature gradients in the East China Sea. Aquat Microb Ecol 17:247-254

Simon M, Azam F (1989) Protein content and protein synthesis rates of planktonic marine bacteria. Mar Ecol Prog Ser 51:201-213

> Teira E, Pazo MJ, Serret P, Fernández E (2001) Dissolved organic carbon production by microbial populations in the Atlantic Ocean. Limnol Oceanogr 46:1370-1377

> Thottathil SD, Balachandran KK, Gupta GVM, Madhu NV, Nair S (2008) Influence of allochthonous input on autotrophic-heterotrophic switch-over in shallow waters of a tropical estuary (Cochin Estuary), India. Estuar Coast Shelf Sci 78:551-562

Tomasky G, Valiela I (1995) Nutrient Limitation of Phytoplankton Growth in Waquoit Bay, Massachusetts. Biol Bull 189:257-258

> Valiela I, Foreman K, LaMontagne M, Hersh D and others (1992) Couplings of watersheds and coastal waters: sources and consequences of nutrient enrichment in Waquoit Bay, Massachusetts. Estuaries 15:443-457

> Valiela I, Collins G, Kremer J, Lajtha K and others (1997) Nitrogen loading from coastal watersheds to receiving estuaries: new method and application. Ecol Appl 7: 358-380

White PA, Kalff J, Rasmussen JB, Gasol JM (1991) The effect of temperature and algal biomass on bacterial production and specific growth rate in freshwater and marine habitats. Microb Ecol 21:99-118

- York JK, Tomasky G, Valiela I, Repeta DJ (2007) Stable isotopic detection of ammonium and nitrate assimilation by phytoplankton in the Waquoit Bay estuarine system. Limnol Oceanogr 52:144-155

Submitted: September 12, 2012; Accepted: May 31, 2013

Proofs received from author(s): August 9, 2013 